\title{
Prevalence of sickle cell disease in tribal peoples of Valsad district region in Gujarat, India
}

\author{
Mistry S. ${ }^{1}$, Shah K. ${ }^{2}$, Patel J. ${ }^{3}$ \\ ${ }^{1}$ Dr. Sunita Mistry, Assistant Professor, ${ }^{2}$ Dr. Kamlesh Shah, Professor, ${ }^{3}$ Dr. Jignasha Patel, Associate Professor; all \\ authors are affiliated with Department of Pathology, GMERS Medical College, Valsad, Gujarat., India.
}

Corresponding Author: Dr. Kamlesh Shah. E-mail: drkjs1964@gmail.com

\begin{abstract}
Background: High prevalence of sickle gene has been demonstrated in various tribal communities of Gujarat including Bhils and Dhodias of Panchmahal, Dublas, Naikas, Koli, Dhanka, Gamit, Vasava, Bariya, Varli, Vaghari, Kukna, Halpati, Chaudhari etc. The present study was conducted with an objective to document the prevalence of sickle cell diseasein Valsad district of Gujarat state. Methodology: The study is conducted as a retrospective survey in GMERS Medical College and hospital, Valsad between January 2015 to December 2016 were screened for sickle cell anemia by sickling test (with freshly prepared sodium metabisulphite). Those found positive for sickling test, were further analyzed by HPLC (high-performance liquid chromatography) to confirm their status as either sickle cell trait or sickle cell disease. Results: Out of 1186 cases number of male cases were 277 (23.35\%) and females were 909 (76.64\%) cases. The gender distribution of male to female cases is $1: 3.88 .7 \%$ cases were sickle cell trait, $9.02 \%$ cases were sickle cell disease, $1.68 \%$ cases were sickle beta thalassemia, $0.25 \%$ cases were B Thalassemia Minor and $0.33 \%$ cases were B Thalassemia Major. In the present study, among the 1186 cases, 397(33.47\%) were from Patel (Dhodia) community, 97 (8.17\%) were from varli community, 57(4.8\%) were from Halpati community and 51(4.3\%) were from Dhodi community followed by other backward community. Conclusion: It was concluded that Dhodias, Varli, Halpati and Dhodi were the most common community of sickle cell disorders in tribal peoples of Valsad district. Among the Sickling test positive cases, Sickle cell trait and sickle cell disease was the most common variant.
\end{abstract}

Keywords: Sickle cell disease, Tribal community, Valsad.

\section{Introduction}

The inherited disorders of blood include hemoglobinopathies which are one of the major public health problems in India[1]. Sickle cell disease is the second most common hemoglobinopathy next to Thalassemia in India [2]. There is a high prevalence of Sickle cell disease in the socio-economically backward groups in India. It is highly prevalent among Scheduled Caste, Scheduled Tribe, and Other Backward Class (10\%)[3].

High prevalence of sickle gene has been demonstrated in various tribal communities of Gujarat including Bhils and Dhodias of Panchmahal, Dublas, Naikas, Koli, Dhanka, Gamit, Vasava, Bariya, Varli, Vaghari, Kukna, Halpati, Chaudharietc [4]. Tribal accounts $15 \%$ of the total population of Gujarat and distributed in various districts of the state such as Sabarkantha, Banaskantha,

Manuscript received: $17^{\text {th }}$ January 2018

Reviewed: $27^{\text {th }}$ January 2018

Author Corrected: $4^{\text {th }}$ February 2018

Accepted for Publication: $10^{\text {th }}$ February 2018
Panchmahal, Vadodara, Narmada, Bharuch, Surat, Valsad, Dang and Div-Daman [5]. The present study was conducted with an objective to document the prevalence of sickle cell diseasein Valsad district of Gujarat state.

\section{Materials and Methods}

The study is conducted as a retrospective survey in a hospital setting. All tribal patients who attended the GMERS Medical college and hospital, Valsad or the state hospitals, PHCs of Valsad district between January 2015 to December 2016 were screened for sickle cell anemia by sickling test (with freshly prepared sodium metabisulphite).

The blood was collected under all aseptic precautions. 2 $\mathrm{ml}$ of blood was drawn from antecubital vein by clean venepuncture from each patient with a sterile plastic syringe and collected in an EDTA (anticoagulant) tube 


\section{Original Research Article}

for determination of investigations like Sickling test, Reticulocyte count. Those found positive for sickling test, were further analyzed by HPLC (high-performance liquid chromatography) to confirm their status as either sickle cell trait or sickle cell disease.
Details were also recorded including age, sex, clinical and laboratory parameters. Categorical variable were expressed in actual number and percentages. Continuous variable were presented as Mean \pm SD.

\section{Results}

There were 1186 samples which were tested positive with Sickling test (DTT test) during the January 2015 to December 2016. The age and gender distribution of cases is according to Table 1. It was seen from Table 1 that among the males 60 $(21.6 \%)$ cases were in $0-10$ years, $64(23.1 \%)$ cases were in $11-20$ years, $68(24.54 \%)$ cases were in $21-30$ years, 44 $(15.88 \%)$ cases were in $31-40$ years, $22(7.94 \%)$ cases were in $41-50$ years, $8(3.97 \%)$ cases were in 51-60 years and 11 (3.97\%) cases were more than 60 years. Among the females 85 (9.35\%) cases were in 0-10 years, 239 (26.29\%) cases were in 11-20 years, $393(43.23 \%)$ cases were in 21-30 years, $104(11.44 \%)$ cases were in 31-40 years, 52 (5.72\%) cases were in 41-50 years, $25(2.75 \%)$ cases were in 51-60 years and $11(1.21 \%)$ cases were more than 60 years. The mean age of the cases participated in the study were $24.9 \pm 13.134$ years.

Table-1: Age and gender distribution of cases.

\begin{tabular}{|c|c|c|c|}
\hline Age (in years) & Male & Female & Total \\
\hline $0-10$ & $60(21.66)$ & $85(9.35)$ & $145(12.22)$ \\
\hline $11-20$ & $64(23.10)$ & $239(26.29)$ & $303(25.54)$ \\
\hline $21-30$ & $68(24.54)$ & $393(43.23)$ & $461(38.87)$ \\
\hline $31-40$ & $44(15.88)$ & $104(11.44)$ & $148(12.47)$ \\
\hline $41-50$ & $22(7.94)$ & $52(5.72)$ & $74(6.23)$ \\
\hline $51-60$ & $8(2.88)$ & $25(2.75)$ & $33(2.78)$ \\
\hline$>60$ & $11(3.97)$ & $11(1.21)$ & $22(1.85)$ \\
\hline Total & $\mathbf{2 7 7 ( 2 3 . 2 5 )}$ & $\mathbf{9 0 9}(\mathbf{7 6 . 6 4})$ & $\mathbf{1 1 8 6}$ \\
\hline
\end{tabular}

Table-2: Types of sickle cell disease

\begin{tabular}{|c|c|c|}
\hline Types of disease & No. & \% \\
\hline Sickle cell trait & 1052 & 88.7 \\
\hline Sickle cell disease & 107 & 9.02 \\
\hline Sickle beta Thalassemia & 20 & 1.68 \\
\hline B Thalassemia Minor & 3 & 0.25 \\
\hline B Thalassemia major & 4 & 0.33 \\
\hline Total & $\mathbf{1 1 8 6}$ & $\mathbf{1 0 0}$ \\
\hline
\end{tabular}

It was seen from the Table 2 that among the 1186 cases, 1052 (88.7\%) cases were sickle cell trait, 107 (9.02\%) cases were sickle cell disease, 20 (1.68\%) cases were sickle beta thalassemia, $3(0.25 \%)$ cases were B Thalassemia Minor and 4 $(0.33 \%)$ cases were B Thalassemia Major.

Table-3: Caste wise distribution of cases

\begin{tabular}{|c|c|c|}
\hline Caste & No. & \% \\
\hline Patel (Dhodia) & 397 & 33.47 \\
\hline Varli & 97 & 8.17 \\
\hline Halpati & 57 & 4.8 \\
\hline Dhodi & 51 & 4.3 \\
\hline Nayka & 48 & 4.04 \\
\hline
\end{tabular}

As far as caste distribution is concerned, it was seen from Table 3 more are belonged to schedule tribe. i.e. Patel (Dhodia) 397 (33.47\%), followed by other backward community, out of which $8.17 \%$ were Varli, $4.8 \%$ were Halpati, $4.3 \%$ were Dhodi and $4.04 \%$ belonged to Nayka. 


\section{Original Research Article}

\section{Discussion}

The population of Gujarat has crossed 6 crores as per Census 2011[6].14.79\% of the population in Gujarat is tribal[7]. Out of total 26 districts of Gujarat; more than half are tribal districts. Gujarat is the 4 th most schedule tribe populated state of India after Madhya Pradesh, Maharashtra and Orissa. The tribal community of Gujarat inhabitants in the geographically difficult terrains of the Eastern belt, extending from Ambaji in the North to Dang in the South Southern Gujarat includes districts of Dangs, Valsad, Navsari, Surat and Bharuch[8].

Gujarat state is expected to have $6,47,025$ Sickle trait and 48,257 Sickle disease patients, belonging to Dhodia, Dubla, Kukna, Gamit, Chaudhary, Halpati, Varli, Kokni, Kathodi, Kolcha, Kotwadiaetc [9]. Sickle cell disease in this tribal area poses difficulty in diagnosis and management, as the sign and symptoms of this disease overlap with other common diseases. Recurrent attacks of musculoskeletal pain, anemia, frequent respiratory infections, jaundice and splenomegaly are the typical features which should arouse suspicion of sickle cell disease. We acknowledge that a community based study is ideal to know the true prevalence of the disease but because of ethical/social issues involved, it is difficult toconduct a community based study involving invasive procedure (blood collection). However, this hospital based survey is important for sensitization and can serve as a baseline for generating more data.

In the present study, out of 1186 participants, 909 were female, which comprised of $76.64 \%$ of the total study population. The gender distribution of male to female cases is 1:3. While in the study done by Awasthy et al in Safdarjung hospital, Delhi, male and female comprised of equal participants [10]. Contrary findings were observed by Kam

ble et al in their study, where male to female ratio was 1.65:1[11]. Among the sickling test positive, $88.7 \%$ cases were sickle test trait. The higher prevalence of the sickle cell trait may be a result of a higher frequency of consanguineous marriages within the relatively small community. Association for Health Welfare in the Nilgiris (ASHWINI), Tamil Nadu also reported prevalence of sickle cell trait in non-tribal Chetti community to be as high as $30 \%$ [12]. Studies by S. L. Kate indicated that the overall prevalence of sickle cell disorder in different tribal populations is $10 \%$ for carrier state and $0.5 \%$ for the sufferer[13]. Sahu T et alreported
$16.55 \%$ prevalence of sickle cell disorder in below fifteen years children in tribal areas of Gajapati district of Orissa[14]. In the present study, majority (33.47\%) of cases belongs toPatel (Dhodia) community followed by Varli, Halpati, Dhodi, Nayka, Dubla and Bhoya. These are the main tribal communities of south Gujrat region. Sahu T et alhas reported Ratia, Sabar, Beera, Mandaletctrible community in their study in south Orissa[14]. The prevalence amongst the different communities in the decreasing order of frequency was Rathod (71.4\%), Vasava (21.4\%), Chavda (3.6\%) and Solanki (3.6\%)[15]. Saxena in his study reported prevalence of sickle cell anemia among Vasava was $26.4 \%$, chaudhari $21.4 \%$, Gamit 20\%, Panchal $13.85 \%$ and among rathod was $8.3 \%[16]$. These observations support the hypothesis that the sickle cell disorders are present in scheduled castes, tribals and few communities of other backward classes (OBC), and not found in so called higher castes; though the review of literature says it is present invariably in all castes[17].

Majority cases were found positive for sickle cell traitor disease belongs to Dhodia community (33.47\%), while Dalal M has reported $18.4 \%$ prevalence of sickle cell trait in Dhodias of south Gujarat region[18]. The variation in proportion of people with different communities dependson their distribution. In Gujarat, the Dhodia, Dubla, Gamit, and Naikatribes have a high prevalence of $\mathrm{HbS}$ (13-31\%)[19].

More recently very extensive population surveys have been done by the Indian Red Cross Society, Gujarat State Branch where 1,68,498 tribals from 22 districts were screened and the overall prevalence of sickle cell carriers was $11.37 \%$ [20]. Some tribal groups in south Gujarat like Chaudry, Gamit, Rohit, Vasava and Kukana have shown both a high prevalence of $\mathrm{HbS}(6.3$ to $22.7 \%$ ) as well as $\beta$-thalassaemia trait (6.3 to $13.6 \%$ ). [21] These tribal groups would have the likelihood of co-inheriting both these genes.

\section{Conclusion}

Study suggested that Sickle cell disease is the most prevalent hemoglobinopathy in South Gujarat. Dhodia, Varli, Halpati, Nayka, Dhodi and other backward community are high risk communities for sickle cell disease among the sickling positive test. Sickle cell trait and sickle cell disease was the most common variant.

Funding: Nil, Conflict of interest: None initiated Permission from IRB: Yes 


\section{Original Research Article}

\section{References}

1. Balgir RS.The burden of hemoglobinopathies in India and the challenges ahead. Curr Sci. 2000;79:1536-47.

2. Agarwal MB, Mehta BC. Sickle syndrome - A study of 44 cases from Bombay. Indian Paediatrics. 1980;17: 793.

3.Kate SL, Lingojwar DP. Epidemiology of Sickle Cell Disorder in the State of Maharashtra. Int J Hum Genet. 2002; 2 (3): 161-67,

4. Sharma RS et al: Hemoglobinopathies in Western India. Journal of Association of Physician India 1973; 2: 969-973.

5. Commissionerate of Tribal Development and Commissionerate of Health and Family Welfare, Govt. of. Gujarat, sickle cell disease control and research project Gujarat, December, 2007.

6. Census of India 2011. Office of the Registrar General and Census Commissioner. Ministry of Home Affairs, Govt of India. Available at: http://www.censusindia. gov.in, Accessed on 2 March 2017.

7. State wise Tribal Population percentage in India; Ministry of Tribal Affairs, Government of India. Available at: http://ribal.nic.in/index 2asp? sublinkid $=545 \&$ langid=1. Accessed on 2 March 2017 .

8. Neena D, Chaudhari S, Nigam S, Joshi T, Shah M, Singh U. Prevalence of sickle cell disorder in rural pipalwada, Gujarat. National J Community Med. 2011;2 (2): $284-8$.

9. Rupani M.P, Vasava B.C, Mallick K.H., Gharat V.V., Bansal R. Reaching Community Through School Going Children for Sickle Cell Disease in Zankhvav Village of Surat District, Western India. Online J Health Allied Scs. 2012;11 (2):4. Available at URL: http:// www.ojhas. org/issue42/2012-24.htm

10. Awasthy N, Aggarwal K C, Goyal P C, Prasad M S, Saluja S, Sharma M. Sickle cell disease: Experience of a tertiary care center in a nonendemic area. Ann Trop Med Public Health 2008;1:1-4
11. Kamble M, Chaturvedi P. Epidemiology of sickle cell disease in a rural hospital of central India. Indian Paediatric. 2000;37:391-6.

12. Association for Health Welfare in the Nilgiris\& Tribal India Health Foundation. Sickle Cell Disease Center, Operations report version 1.4. www.tihf.org/ scd.htm.

13. Kate S.L. Health Problems of Tribal Population Groups from the State of Maharashtra. Imuunohaematology Bulletin Oct. 23, 2000.

14. Sahu T, Sahani NC, Das S, Sahu SK. Sickle cell anemia in tribal children of Gajapati district in south Orissa. Ind J Comm Med 2003; 28: 180-183.

15. Doshi Neena, Chaudhari Sanjay, Shah Nigam, Joshi Trupti, Shah Menka, Uday Singh. Prevalence of sickle cell disorder in rural Pipalwada, Gujarat. National Journal of Community Medicine Vol 2 Issue 2 JulySept 2011 p-284-88.

16.Saxena D. Study of prevalence of Sickle cell disease in students of three randomly selected schools of Umarpada taluka. Health line J. 2004;5(1\&2):19-22.

17. Deshmukh P. et al. Prevalence of Sickle Cell Disorders in Rural Wardha. IJCM 2006; 31(1)

18. Dalal M Study of sickle cell diseases in tribal population.Thesis submitted to South Gujrat University, Surat 1994.

19. Bhatia HM, Rao VR. Genetic atlas of Indian Tribes, Bombay: Institute of Immunohaematology (ICMR); 1987.

20. Patel AP, Naik MR, Shah NM, Sharma N, Parmar P. Prevalence of common hemoglobinopathies in Gujarat: An analysis of a large population screening programme. Natl J Community Med 2012; 3 : 112-6.

21. Patel AG, Shah AP, Sorathiya SM, Gupte SC. Hemoglobinopathies in South Gujarat population and incidence of anemia in them. Indian J Hum Genet 2012; $18: 294-8$.

\section{How to cite this article?}

Mistry S, Shah K, Patel J. Prevalence of sickle cell disease in tribal peoples of Valsad district region in Gujarat, India. Trop J Path Micro 2018;4(1):109-112. doi: 10.17511/jopm.2018.i1.19. 